Crop Breeding and Applied Biotechnology 14: 102-107 2014

Brazilian Society of Plant Breeding. Printed in Brazil

\title{
ARTICLE
}

http://dx.doi.org/10.1590/1984-70332014v14n2a18

\section{Efficiency of biparental crossing in sugarcane analyzed by SSR markers}

\author{
João Messias dos Santos ${ }^{1}$, Geraldo Veríssimo de Souza Barbosa ${ }^{1}$, Cícero Eduardo Ramalho Neto ${ }^{2}$ and Cícero Almeida ${ }^{3 *}$
}

Received 04 April 2013

Accepted 15 January 2014

\begin{abstract}
Sugarcane has hermaphrodite flowers, however, selfing and cross pollination may occur, resulting in selfed or hybrid progeny. The aim of this study was to analyze the paternity of progenies from biparental crosses, in order to identify true hybrids or progenies originating from pollen of unknown origin. Seventy-six progenies from four crosses were analyzed using three highly polymorphic microsatellite markers (SSR). Progenies showed moderate genetic similarity and were grouped into four distinct groups, according to the crosses. Transmission of alleles from parents to offspring was clearly observed, in which selfed individuals were not observed, and only true hybrids or progeny resulting from fertilization with pollen uncommon to both parents were. Results showed that there was contamination with pollen from unknown parents in sugarcane crosses, suggesting that errors in the pedigree may occur, and adjustment in the crossing procedure would decrease progenies from pollen of unknown origin.
\end{abstract}

Key words: Saccharum, microsatellites, plant breeding.

\section{INTRODUCTION}

Commercial varieties of sugarcane are hybrids from biparental or polycross crossings (pollen of various genotypes are used to fertilize female flowers) (Heinz and Tew 1987). Biparental crossing is frequently used in breeding programs; however, polycross crossings are most utilized since they are economical and efficient in producing seeds, especially when there are few panicles on the parent (Ramdoyal et al. 2003).

Sugarcane has hermaphrodite flowers, and pollination is accomplished by cross-pollination. However, either self-pollination or cross-pollination with foreign pollen can occur in breeding programs (Ferreira et al. 2005), resulting in selfing or foreign progenies (McIntyre and Jackson 2001, Chen et al. 2009). To minimize self-pollination in progeny numbers, maternal flowers are immersed in heated water at $50{ }^{\circ} \mathrm{C}$ for $4.5 \mathrm{~min}$ to sterilize them before crossings are carried out (Machado Jr et al. 1995). However, Pan et al. (2003) showed that complete pollen sterility has not been efficient, suggesting the occurrence of hybrid and selfing progenies in the $\mathrm{F}_{1}$ population.
Breeders have used morphological traits to identify hybrids and selfing progenies; however, morphological traits are largely affected by plant development and highly influenced by the environment, indicating that they are not suitable as a form of identification (Cai et al. 2005, Romero et al. 2009, Wang et al. 2009, Tew and Pan 2010). Alternatively, DNA molecular markers can be used to identify progenies accurately (Silva et al. 2012a). Among the molecular markers, microsatellites or SSR (Simple Sequence Repeats) present important advantages, such as having high variability, being multiallelic, having codominance, being highly reproducible, being abundant in the genomes, and having a specific location on chromosomes (Kalia et al. 2011). SSR markers have been reported in sugarcane (Pan 2006, Silva et al. 2012a, Silva et al. 2012b), which demonstrated that SSR can be utilized for correct identification of individuals in sugarcane. However, there have not been reports for assisted crossings in sugarcane breeding programs. In the current study, SSR molecular markers were used to analyze the efficiency of biparental crossing in sugarcane and to demonstrate the applicability of SSR markers in sugarcane breeding.

\footnotetext{
${ }^{1}$ Universidade Federal de Alagoas (UFAL), Centro de Ciências Agrárias, RIDESA, Campus Delza Gitaí, BR104 norte, km 85, 57.072-900, Rio Largo, AL, Brazil ${ }^{2}$ UFAL, Laboratório de Genômica e Proteômica

${ }^{3}$ UFAL, Laboratório de Recursos Genéticos, Campus Arapiraca, Avenida Manoel Severino Barbosa s/n, Rodovia AL 115, km 6,5, Bairro Bom Sucesso, 57.300-970, Arapiraca, AL, Brazil. *E-mail: cicerocarlos@hotmail.com
} 


\section{MATERIAL AND METHODS}

\section{Plant material}

$F_{1}$ progenies from the following crossings were analyzed: nineteen from RB863129 x SP93-3500; twenty from SP83-2847 x RB98710; twenty from RB991555 x SP80-1816; and seventeen from RB845210 x H64-1881. These progenies were obtained using standard procedures at the RIDESA sugarcane breeding program (Barbosa et al. 2002), where plants were cultivated in the field before opening of the anthers, and subsequently protected to avoid contamination from foreign pollen. Plants were cultivated in Hawaiian nutrient solution (Heinz and Tew 1987) for the duration of the experiment. For 15 days, male and female inflorescences were shaken daily (at 6 am) to provide the crossings, and were then isolated for an additional 15 days to complete the development and maturation of caryopses. Spikelets with caryopses were harvested, dried at $38{ }^{\circ} \mathrm{C}$, and stored at $-5^{\circ} \mathrm{C}$. Caryopses ( $3 \mathrm{~g}$ ) were then germinated, and after 20 days, seedlings were transplanted to plastic tubes.

\section{DNA extraction and microsatellites analysis}

DNA was isolated from the tissues of young leaves, using the procedure described by Saghai-Maroof et al. (1984). Concentration was determined by spectrophotometry, and integrity by electrophoresis in $1 \%$ agarose gel. Two SSR markers developed by Duarte-Filho et al. (2010) (SCC06, SCC05), and one (SCC92) by Silva et al. (2012b) were used. For PCR amplification, a final volume of $50 \mu \mathrm{L}$ was used containing: $25 \mathrm{ng}$ of genomic DNA, $10 \mathrm{X}$ buffer, 2.0 $\mathrm{mM} \mathrm{MgCl}, 0.2 \mathrm{mM}$ dNTP, $1.50 \mathrm{U}$ Taq-DNA polymerase, 30 pmol of each primer (forward and reverse), and sterile distilled water. PCR amplifications were carried out in a thermal cycler (Veriti Fast 96 Well Applied Biosystems), with 35 cycles at $94{ }^{\circ} \mathrm{C}$ for $1 \mathrm{~min}, 60^{\circ} \mathrm{C}$ for $1 \mathrm{~min}, 72{ }^{\circ} \mathrm{C}$ for $1 \mathrm{~min}$, and a final extension of $72^{\circ} \mathrm{C}$ for $10 \mathrm{~min}$. Forward primers for each molecular marker were labeled with different fluorescent dyes (6FAM or HEX) and arranged in duplex for analysis in an automated fragments sequencer (ABI-3730, Applied Biosystems). 400DH GeneScan (Applied Biosystems, Foster City, CA) was used to accurately determine the size of fragments detected by capillary electrophoresis. These fragments were visualized as peaks with the respective sizes and intensities using Peak Scanner software version 1.0 (Applied Biosystems).

\section{Data analysis}

Despite being considered co-dominant SSR markers, in this study they were considered as dominant markers since in highly polyploid genomes such as that of sugarcane SSR markers have difficulty distinguishing the alleles of homologous chromosomes, making it difficult to determine heterozygosity or homozygosity at any particular locus (Cordeiro et al. 2003, Oliveira et al. 2009). From this assumption, all possible alleles detected in the varieties have been converted to a binary system.

For each individual, clear and distinct peaks were classified as absent (0) or present (1) to form the matrix that was used to estimate the following variables.

Number of alleles as absent or present among genotypes $\left(\mathrm{N}_{\mathrm{p}}\right)$

Number of alleles only as present among genotypes $\left(\mathrm{N}_{\mathrm{np}}\right)$

Polymorphism information content (PIC) obtained through the expression: $\mathrm{PIC}=1-\sum p i j^{2}$, where $p i$ is the frequency of allele $i$ for the $j$ th marker (Powell et al. 1996).

Genetic similarity (GS) was calculated using the Jaccard coefficient, obtained by the expression: $\mathrm{GS}=\mathrm{a} /(\mathrm{a}+\mathrm{b}+$ c), where $a$ is the number of positive coincidences (1) in both genotypes, $b$ is the negative number $(0)$ for genotype $i$ and positive (1) for genotype $j$, c is the positive number (1) for genotype $i$ and negative (0) for genotype $j$ (Reif et al. 2005). Jaccard similarity values were used to generate a clustering using the UPGMA procedure. Analyses were performed using R software (version 2.15.3) package.

Based on the microsatellite profile, the offspring of each crossing were classified as true hybrids, selfing or foreign. The presence of specific alleles from the mother and the father in the progeny indicated that the individual is a true hybrid. If the progeny had only alleles from the female parent, it was classified as selfing, and when some alleles were not found in either parent, the progeny was classified as foreign.

\section{RESULTS AND DISCUSSION}

Results showed a total of 48 alleles, where only one $(2.08 \%)$ was present in all genotypes, and allele's size ranged from 87 to $226 \mathrm{bp}$. Forty-seven alleles considered as absent or present among genotypes $(97.92 \%)$ were used to estimate the genetic similarity among parents and progenies of four different sugarcane populations. The number of alleles amplified per individual for three SSR markers ranged from 12 to 31 with an average of 16.82 alleles. In all progenies, microsatellite markers SCC05, SCC06 and SCC92 produced 18, 12 and 18 alleles, respectively. Average PIC was 0.86 , and ranged from 0.80 to 0.91 , showing that markers are highly polymorphic (Table 1$)$. 
JM Santos et al.

Table 1. Polymorphic information content (PIC), number of alleles as absent or present among genotypes $\left(\mathrm{N}_{\mathrm{p}}\right)$, number of alleles only as present among genotypes $\left(\mathrm{N}_{\mathrm{np}}\right)$, allelic interval $(\mathrm{bp})$ and number of alleles per individual

\begin{tabular}{llllll}
\hline SSR & PIC & $\mathbf{N}_{p}$ & $\mathbf{N}_{n p}$ & Allelic interval (bp) & Number of alleles per individual \\
\hline SCC05 & 0.91 & 18 & 0 & $114-194$ & $4-11$ \\
SCC06 & 0.80 & 11 & 1 & $177-226$ & $2-8$ \\
SCC92 & 0.86 & 18 & 0 & $87-187$ & $1-16$ \\
\hline Mean & 0.86 & 15.66 & 0.33 & 158.22 & 5.61 \\
\hline Total & - & 47 & 1 & - & $12-31$ \\
\hline
\end{tabular}

Genetic similarities were calculated among progenies and parents for each crossing, and among all 76 progenies using the Jaccard coefficient (Reif et al. 2005). The average genetic similarity of crossings RB863129 x SP93-3500, SP83-2847 x RB98710, RB991555 x SP80-1816 and RB845210 x H64-1881 were 0.56, 0.55, 0.61 and 0.50 respectively. When using all progenies and parents (3.586 pairwise), genetic similarities ranged from 0.16 to 0.95 , with an average of 0.45 . The four populations were analyzed by cluster analysis, and the dendrogram showed four groups, corresponding to the crossings. Some exceptions were observed due to the presence of foreign pollen in particular progenies (Figure 1).

Specific alleles of female or male parent, and common alleles of both parents of each crossing were identified (Figure 2). Results ranged from 3 to 16 specific alleles for female parents, with an average of 7.25. For male parents, the number was from 7 to 9 , with an average of 8.25. Common alleles ranged from 14 to 17 alleles, with an average of 15 common alleles for each crossing (Table 2).

For crossing RB863129 x SP93-3500, 84.21\% were identified as true hybrids, and $15.79 \%$ were classified as foreign (Table 2 and Figure 2). Similarly, progenies from foreign pollen in the crossing SP83-2847 x RB98710 were observed; however, with a higher percentage (80\%) for foreign, and 20\% for true hybrids (Table 2 and Figure 2). On the other hand, all alleles observed in 37 progenies

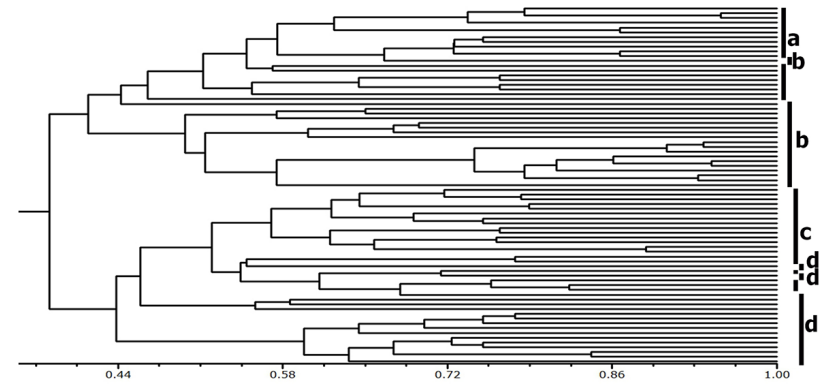

Figure 1. Dendrogram showing the relationships among 76 progenies of sugarcane based on cluster analysis (UPGMA) using genetic similarity (Jaccard coefficient). Crossings: RB863129 x SP93-3500 (a), SP83-2847 x RB98710 (b), RB991555 x SP80-1816 (c) and RB845210 x H64-1881 (d). from crossings RB991555 x SP80-1816 and RB845210 x H64-1881 were inherited from their parents (Table 2 and Figure 2), showing as true hybrids.

According to Wang et al. (2009), sugarcane and its related species share many phenotypic characteristics, which make it difficult to identify true hybrids based on morphological traits criteria. Although both parents carry different morphophysiological traits, offspring may show variation due to polyploidy, aneuploidy and high chromosome segregation resulting from interspecific hybridization and environmental influence. Therefore, the correct identification of true hybrids requires alternative methods. This study shows the first approach for the analysis of offspring for identifying selfing and foreign pollen in biparental crossings, using SSR markers.

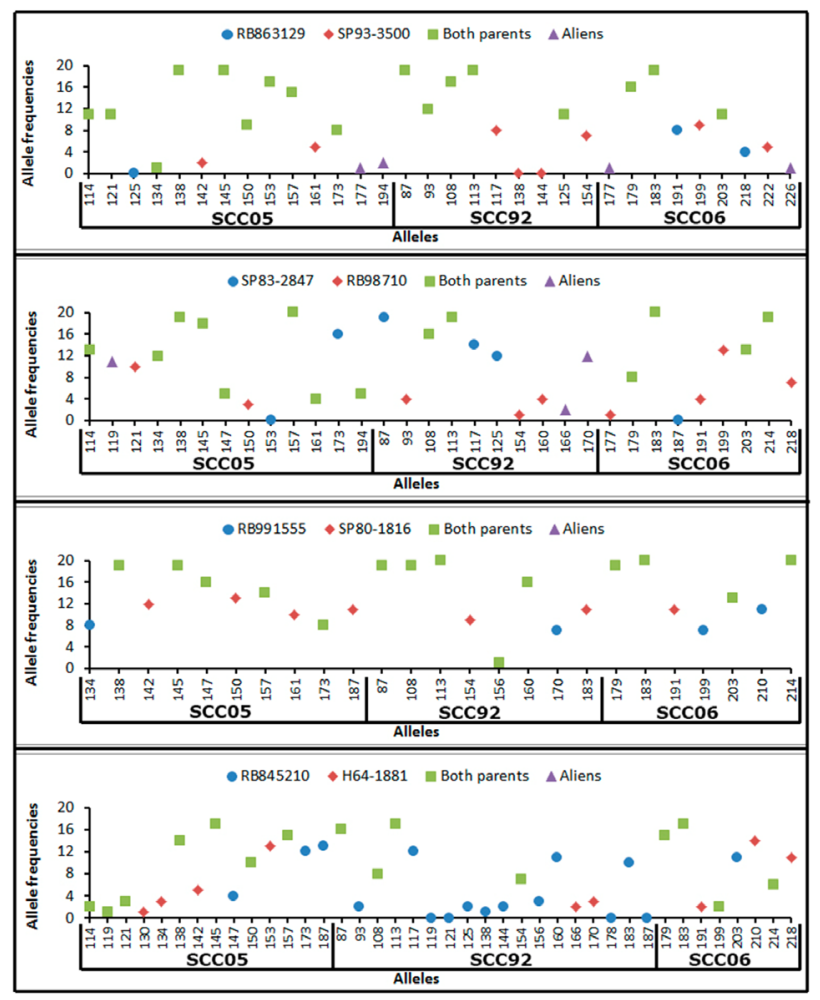

Figure 2. Allele frequencies among progenies from four sugarcane crosses. 
Table 2. Varieties used as parents, sex classification of each parent, number of SSR alleles unique to the male and female parents, number of common SSR alleles, contaminants (\%) detected for each crossing. Sex classification of each parent $(\mathrm{F}=$ female, $\mathrm{M}=\mathrm{male}, \mathrm{B}=\mathrm{bisexual})$

\begin{tabular}{|c|c|c|c|c|c|c|c|c|}
\hline \multirow[b]{2}{*}{$\mathbf{N}$} & \multicolumn{4}{|l|}{ Parents } & \multicolumn{2}{|c|}{ Exclusive alleles } & \multirow{2}{*}{$\begin{array}{l}\text { Common alleles } \\
+\mathbf{x} \curvearrowright\end{array}$} & \multirow{2}{*}{ Contaminants (\%) } \\
\hline & Female ( + ) & Sex & Male $\left({ }^{\circledR}\right)$ & Sex & q & $\hat{\sigma}$ & & \\
\hline 19 & RB863129 & $\mathrm{B}$ & SP93-3500 & $\mathrm{B}$ & 3 & 8 & 17 & 15.79 \\
\hline 20 & SP83-2847 & M & RB98710 & $\mathrm{F}$ & 6 & 9 & 14 & 80.00 \\
\hline 20 & RB991555 & B & SP80-1816 & M & 4 & 7 & 14 & 0.00 \\
\hline 17 & RB845210 & M & H64-1881 & M & 16 & 9 & 15 & 0.00 \\
\hline Mean & & & & & 7.25 & 8.25 & 15 & 23.95 \\
\hline
\end{tabular}

In the results, three SSR markers were used to generate DNA profiles for parents and offspring. A high number of alleles per locus were detected, corroborating other studies using microsatellites markers in sugarcane accessions (Santos et al. 2012, Silva et al. 2012a), and the combination of three SSR loci used in this study identified all genotypes. Indeed, Maccheroni et al. (2009) and Silva et al. (2012a) showed the high discriminatory power of SSR markers in sugarcane genotypes.

Genetic similarity average was moderate, which is explained by the high polyploidy in sugarcane. In all genotypes analyzed, only eight parents would produce all offspring; however, the presence of foreign pollen decreased the genetic similarities among genotypes. In other studies with SSR markers, moderate genetic similarity coefficients have been reported, suggesting common values among modern sugarcane genotypes (Lima et al. 2002, Pinto et al. 2006, Creste et al. 2010, Santos et al. 2012, Silva et al. 2012a). Despite the large number of progenies due to foreign pollen for the crossing SP83-2847 x RB98710, there was formation of four well-defined groups.

Transmission of alleles from parents to offspring was clearly observed, indicating that SSR markers can be useful for identifying true hybrids and contaminants in sugarcane crosses. It was not identified any individual resulting from selfing, even using female parents with high pollen fertility (Table 2). However, two progenies from the crossing RB863129 x SP93-3500 showed inconclusive results since they didn't show exclusive male parental alleles. Given that most of the alleles inherited by these progenies are common between the two possible parents, it is not possible to state for sure that they are true hybrids since it is not known if these common alleles are of maternal and/or paternal origin. If the origin of all these common alleles is maternal, then there would be only two progenies result of selfing in this study.

These results suggest that the occurrence of selfing in the RIDESA sugarcane breeding program is usually very low. One hypothesis to explain the possible absence of natural selfing in this study is the occurrence of physiological and/or morphological mechanisms that promote cross-pollination in the four varieties used as females. In studies by McIntyre and Jackson (2001), the low number of selfing found in parents classified as bisexual suggests the possibility of the use of clones with moderate amounts of pollen production as females, which may decrease selfing in the offspring.

Skinner (1966) reported that when genotype predominantly male were used as females, they produced almost all hybrid progenies when crossed with other males. Machado Jr. et al. (1995), when studying the inflorescence of four varieties, suggested low frequency of natural selfing when the pollen of other varieties are present. McIntyre and Jackson (2001) and Nagarajan et al. (2001) evaluated progenies using molecular and morphological markers, respectively, and found a selfing percentage ranging from $0.00 \%$ to $17.60 \%$, assuming that the extent of selfing in crossings of sugarcane is very low, and therefore breeders do not need to concern about it. According to Nagarajan et al. (2001), sugarcane is cross-pollinated; it prefers pollen from other parents, significantly reducing the amount of selfing. Tew and Pan (2010) evaluated 609 sugarcane progenies from seven crosses, and found that selfing ranged from 0.00 to $45.00 \%$.

On the other hand, it was found that $23.95 \%$ of offspring were not true hybrids. This may be due to the occurrence of crossing before pairing of the parents, or a lack of isolation of panicles during caryopses maturation, promoting contamination. Contrary to the present results, Tew and Pan (2010) found that only $6.89 \%$ of offspring were from foreign pollen. It was concluded that the frequency of selfing in the offspring from the sugarcane crosses evaluated is very low; however, a moderate number of individuals from foreign pollen were observed, suggesting that biparental or polycross crossings are not totally efficient. Results suggest adjustment in crossing methods in sugarcane breeding to avoid contamination with foreign pollen, and the use of molecular markers in new varieties is necessary to confirm the genealogy. 


\section{ACKNOWLEDGEMENTS}

This work was supported by the RIDESA (Rede Inter- universitária para o Desenvolvimento do Setor Sucroenergético) breeding program and the Conselho Nacional de Desenvolvimento Científico e Tecnológico (CNPq), Brazil.

\section{Eficiência de cruzamentos biparental em cana-de-açúcar analisada por marcadores SSR}

Resumo - Cana-de-açúcar possui flores hermafroditas, no entanto, autofecundação e polinização cruzada podem ocorrer, resultando em progênies autofecundadas ou híbridas. O objetivo do presente estudo foi analisar a paternidade de progênies provenientes de cruzamentos biparental, para identificar hibridos verdadeiros ou progênies formadas a partir de pólen de origem desconhecida. Setenta e seis progênies de quatro cruzamentos foram analisadas usando três marcadores moleculares microssatélites (SSR) altamente polimórficos. As progênies mostraram moderada similaridade genética e foram agrupadas em quatro distintos grupos, conforme os cruzamentos. A transmissão dos alelos dos parentais para a descendência foi claramente observada, em que não foram observados individuos autofecundados, somente hibridos verdadeiros ou progênies resultante da fecundação de pólen incomum a ambos os parentais. Os resultados mostraram que existe contaminação com pólen de genitores desconhecidos em cruzamentos em cana-de-açúcar, sugerindo que erros no pedigree podem ocorrer.

Palavras-chave: Saccharum, microssatélites, melhoramento de plantas.

\section{REFERENCES}

Barbosa GVS, Cruz MM, Soares L, Rocha AMC, Ribeiro AAG, Sousa AJR, Ferreira JLC, Barreto EJS, Da Silva WCM and Santos AVPA (2002) Brief report on sugarcane breeding program in Alagoas, Brazil. Crop Breeding and Applied Biotechnology 2: 613-616.

Cai Q, Aitken K, Deng HH, Chen XW, Fu C, Jackson PA and McIntyre CL (2005) Verification of the introgression of Erianthus arundinaceus germplasm into sugarcane using molecular markers. Plant Breeding 124: $322-328$.

Chen PH, Pan YB, Chen RK, Xu LP and Chen YQ (2009) SSR marker based analysis of genetic relatedness among sugarcane cultivars (Saccharum spp. hybrids) from breeding programs in China and other countries. Sugar Tech 11: 347-354.

Cordeiro GM, Pan YB and Henry RJ (2003) Sugarcane microsatellites for the assessment of genetic diversity in sugarcane germplasm. Plant Science 165: 181-189.

Creste S, Sansoli DM, Tardiani ACS, Silva DN, Gonçalves FK, Fávero TM, Medeiros CNF, Festucci CS, Carlini-Garcia LA, Landell MGA and Pinto LR (2010) Comparison of AFLP TRAP and SSRs in the estimation of genetic relationships in sugarcane. Sugar Tech 12: 150-154.

Duarte-Filho LSC, Silva PP, Santos JM, Barbosa GVS, Ramalho Neto CE, Soares L, Andrade JCF and Almeida C (2010) Genetic similarity among genotypes of sugarcane estimated by SSR and coefficient of parentage. Sugar Tech 12: 145-149.

Ferreira FM, Barbosa MHP, Castro RD, Peternelli LA and Cruz CD (2005) Effects of inbreeding on the selection of sugarcane clones. Crop Breeding Applied Biotechnology 5: 174-182.

Heinz DJ and Tew TL (1987) Hybridization procedures. In Heinz DJ (ed) Sugarcane improvement through breeding. Elsevier, Amsterdam, p. 313-342.

Kalia RK, Rai MK, Singh SKR and Dhawan AK (2011) Microsatellite markers: an overview of the recent progress in plants. Euphytica
177: 309-334.

Lima MLA, Garcia AAF, Oliveira KM, Matsuoka S, Arizono H, Souza Jr CL and Souza AP (2002) Analysis of genetic similarity detected by AFLP and coefficient of parentage among genotype of sugarcane (Saccharum spp.). Theoretical Applied Genetics 104: 30-38.

Maccheroni W, Jordão H, Gaspari R, Moura GL and Matsuoka C (2009) Development of a dependable microsatellite-based fingerprinting system for sugarcane. In Proceedings of international society of sugar cane techonogists. ICC, Durban, p. 889-900.

Machado Jr. GR, Walker DI, Bressiani JA and Da Silva JAG (1995) Emasculation of sugarcane tassels using hot water. In Proceedings of international society of sugar cane techonogists. ISSCT, Cartagena, p. 346-352.

McIntyre CL and Jackson PA(2001) Low level of selfing found in a sample of crosses in Australian sugarcane breeding programs. Euphytica 117: $245-249$.

Nagarajan R, Alarmelu RS, Shanthi RM and Dhamodharan S (2001) A note on extent of selfing in interspecific crosses of Saccharum. Sugar Tech 3: 180-181.

Oliveira KM, Pinto LR, Marconi TG, Mollinari M, Ulian EC, Chabregas SM, Falco MC, Burnquist W, Garcia AAF and Souza AP (2009) Characterization of new polymorphic functional markers for sugarcane. Genome 52: 191-209.

Pan YB (2006) Highly polymorphic microsatellite DNA markers for sugarcane germplasm evaluation and variety identity testing. Sugar Tech 8: 246-256.

Pan YB, Cordeiro GM, Richard Jr. EP and Henry RJ (2003) Molecular genotyping of sugarcane clones with microsatellite DNA markers. Maydica 48: 319-329.

Pinto LR, Oliveira KM, Marconi T, Garcia AAF, Ulian EC and De Souza AP (2006) Characterization of novel sugarcane expressed sequence tag microsatellites and their comparison with genomic SSRs. Plant Breeding 125: 378-384. 
Powell W, Morgante C, Andre M, Hanafey J, Vogel T and Rafalski A(1996) The comparison of RFLP, RAPD, AFLP, and SSR (microsatellite) markers for germplasm analysis. Molecular Breeding 2: 225-238.

Ramdoyal K, Badaloo GH and Goburdhun P (2003) An international survey of sugar cane crossing programmes. Sugar Cane International 1008: 3-11.

Reif JC, Melchinger AE and Frisch M (2005) Genetical and mathematical properties of similarity and dissimilarity coefficients applied in plant breeding and seed bank management. Crop Science 45: 1-7.

Romero G, Adeva A and Battad II Z (2009) Genetic fingerprinting: Advancing the frontiers of crop biology research. Philippine Science Letters 2: 8-13.

Saghai-Maroof MA, Soliman KM, Jorgensen RA and Allard RW (1984) Ribosomal DNA spacer-length polymorphisms in barley-mendelian inheritance, chromosomal location, and population-dynamics. Proceedings of the National Academy of Sciences 81: 8014-8018.

Santos JM, Duarte Filho LSC, Soriano ML, Silva PP, Nascimento VX, Barbosa GVS, Todaro AR, Ramalho Neto CE and Almeida C (2012) Genetic diversity of the main progenitors of sugarcane from the
RIDESA germplasm bank using SSR markers. Industrial Crops and Products 40: 145-150.

Silva DC, Duarte Filho LSC, Santos JM, Barbosa GV and Almeida C (2012a) DNA fingerprinting based on simple sequence repeat (SSR) markers in sugarcane clones from the breeding program RIDESA. African Journal of Biotechnology 11: 4722-4728.

Silva DC, Souza MCP, Duarte Filho LSC, Santos JM, Barbosa GVS and Almeida C (2012b) New polymorphic EST-SSR markers in sugarcane. Sugar Tech 14: 357-363.

Skinner JC (1966) Use of mixed variety plots to measure gains from selection and effects of self-pollination. Sugarcane Breeders' Newsletter 17: 10-141.

Tew TL and Pan YB (2010) Microsatellite (Simple Sequence Repeat) marker-based paternity analysis of a seven-parent sugarcane polycross. Crop Science 50: 1401-1408.

Wang XH, Yang QH, Li FS, He LL and He SC (2009) Molecular identification of Saccharum spp $\times$ Erianthus fulvus hybrids using sequence-characterized amplified region markers Crop Science 49: 864-870. 